\title{
The study of severe asthma in Latin America and Spain (1994-2004): characteristics of patients hospitalized with acute severe asthma*,**
}

\author{
Estudo sobre Asma Grave na América Latina e Espanha (1994-2004): \\ características dos pacientes hospitalizados com asma aguda grave \\ Gustavo Javier Rodrigo, Vicente Plaza, Jesús Bellido-Casado, \\ Hugo Neffen, María Teresa Bazús, Gur Levy, Joseph Armengol
}

\begin{abstract}
Objective: Studies assessing the characteristics and management of patients hospitalized with asthma have been limited to a small number of facilities and have evaluated short time periods. The present study evaluated long-term changes among hospitalized asthma patients at a large number of facilities. Methods: This was a retrospective, hospital-based observational case series, designated the Study of Severe Asthma in Latin America and Spain, which was conducted in Spain and in eight Latin-American countries. We reviewed the hospital records of 3,038 patients (age range, 15-69 years) hospitalized with acute severe asthma at one of nineteen tertiary-care hospitals in 1994, 1999 and 2004. Results: Over time, the use of inhaled corticosteroids and long-acting $\beta_{2}$ agonists increased significantly, whereas the use of theophylline as a controller medication decreased. The utilization of pulmonary function tests also increased. There was a significant reduction in the mean hospital stay (8.5 days, 7.4 days and 7.1 days in 1994, 1999 and 2004, respectively, $p=0.0001$ ) and a significant increase in the mean of the lowest arterial $\mathrm{pH}$ at hospital admission. In contrast, there was a significant decrease in the proportion of cases in which PEF was determined in the emergency room (48.6\% in $1994 \mathrm{vs.} 43.5 \%$ in $2004, p=0.0001)$. We found the quality of asthma management and care to be generally better in Spain than in Latin America. Conclusions: Although there have been certain improvements in the management of asthma between severe exacerbations and during hospitalization, asthma management remains suboptimal in Spain and, especially, in Latin America.
\end{abstract}

Keywords: Status asthmaticus; Asthma/therapy; Hospitalization.

\section{Resumo}

Objetivo: Estudos que avaliem as características e o gerenciamento de pacientes asmáticos hospitalizados têm sido limitados a um número pequeno de serviços e a curtos períodos de duração. 0 presente estudo avaliou alterações de longo prazo de pacientes asmáticos hospitalizados em um grande número de serviços. Métodos: Estudo retrospectivo, observacional, de base hospitalar, denominado Estudo sobre Asma Grave na América Latina e Espanha, realizado na Espanha e em oito países da América Latina. Foi realizada uma revisão dos registros hospitalares de 3.038 pacientes (variação de idade, 15-69 anos) hospitalizados com asma aguda grave em um dos 19 hospitais terciários em 1994, 1999 e 2004. Resultados: Ao longo do tempo, o uso de corticosteroides inalatórios e de $\beta_{2}$-agonistas aumentou significativamente, ao passo que o uso de teofilina, como medicação de controle, decaiu. A utilização de testes de função pulmonar também aumentou. Houve uma redução significativa da média do tempo de internação (8,5 dias, 7,4 dias e 7,1 dias em 1994, 1999 e 2004, respectivamente; $p=0,0001)$ e um aumento significativo da média do menor $\mathrm{pH}$ arterial na admissão. Em contrapartida, houve uma diminuição significativa na proporção de casos submetidos ao PFE no pronto-socorro (48,6\% em 1994 vs. 43,5\% em 2004; $p=0,0001)$. 0 tratamento e o gerenciamento da asma foram, de forma geral, melhores na Espanha que na América Latina. Conclusões: Embora tenha havido avanços no gerenciamento da asma entre exacerbações graves e durante a hospitalização, esse gerenciamento continua subotimizado na Espanha e, em especial, na América Latina.

Descritores: Estado asmático; Asma/terapia; Hospitalização.

\footnotetext{
* Study carried out at the following locations: the Department of Emergency Services, Hospital Central de las Fuerzas Armadas, Montevideo, Uruguay; the Department of Pulmonology, Hospital de la Santa Creu i Sant Pau, Barcelona, Spain; the Department of Respiratory Medicine, Hospital de Niños "O. Allassia”, Santa Fe, Argentina; the Department of Pulmonology, National Silicosis Institute, Oviedo, Spain; the Department of Pulmonology, Hospital Universitario de Caracas, Central University of Venezuela, Caracas, Venezuela; and the Department of Pulmonology, Hospital de Terrassa, Terrassa, Spain.

Correspondence to: Gustavo Javier Rodrigo. Departamento de Emergencia, Hospital Central de las Fuerzas Armadas, Av. 8 de Octubre 3020, Montevideo, 11600, Uruguay.

Tel 5982 487-0165. Fax 5982 487-2506. E-mail: gurodrig@adinet.com.uy

Financial support: This study received financial support from AstraZeneca, Spain, as part of the Programa de Investigación Integrada (Pll, Integrated lnvestigation Program) of the Asthma Section of the Sociedad Española de Neumologia y Cirugía Torácica (SEPAR, Spanish Society of Pulmonology and Thoracic Surgery). AstraZeneca was not involved in data collection or interpretation, nor was it involved in the writing of the manuscript.

Submitted: 8 January 2009. Accepted, after review: 26 February 2009.

** A versão completa em português deste artigo está disponível em www.jornaldepneumologia.com.br
} 


\section{Introduction}

Asthma is one of the most common chronic diseases worldwide. ${ }^{(1)}$ In the United States, it is responsible for more than 1.5 million emergency room visits, approximately 500,000 hospitalizations and almost 5,000 deaths each year. ${ }^{(2)}$ In the last decade, there have been various improvements in the diagnosis and treatment of asthma. The emphasis has shifted toward patient education, objective measures of the degree of bronchial obstruction and the use of inhaled corticosteroids for the prevention of exacerbations. ${ }^{(3)}$ Despite these improvements, many authors have reported underuse of inhaled corticosteroids and inadequate assessment of airway obstruction. ${ }^{(4)}$ However, there have been few studies that assessed the changes in asthma management over time. In general, such studies have evaluated cases over short periods of time and have been limited in their scope: conducted in individual facilities, limited to a small number of facilities or restricted to prescribed urban areas. ${ }^{(5-8)}$ In view of this lack of information, we conducted a study to evaluate modifications in the characteristics of patients hospitalized with acute severe asthma over a ten-year period (1994-2004), in Spain and in eight Latin-American countries.

\section{Methods}

This project, designated the Estudio del Asma Grave en Latinoamérica y España (EAGLE, Study of Severe Asthma in Latin America and Spain), was promoted by the respective asthma sections of the Spanish Society of Pulmonology and Thoracic Surgery and the Latin-American Thoracic Association. The study sample included all inpatient ( $>48 \mathrm{~h}$ ) hospital admissions for acute severe asthma at nineteen tertiary-care hospitals in Spain (nine facilities) and Latin America (ten facilities) occurring in 1994, 1999 and 2004. Hospital eligibility, in all three of the selected years, was based on having more than 200 beds, an active emergency room and a functioning intensive care unit (ICU). We retrospectively identified and reviewed all hospital records for patients from 15 to 69 years of age admitted with a primary diagnosis of acute asthma, as defined in the ninth and tenth revisions of the International Classification of Diseases (codes 493.01 and J45;J46, respectively). The local ethics committees approved the study design. The analysis was restricted to the last admission of each patient in each year. We conducted a detailed review of the records in order to collect data related to the following: age; gender; year and month of admission; use of inhaled corticosteroids and long-acting $\beta_{2}$ agonists; use of theophylline as a controller medication; dose of inhaled corticosteroids (micrograms of beclomethasone or equivalent); asthma severity, according to the Global Initiative for Asthma criteria $^{(1)}$; measurements of allergenicity (skinprick test, radioallergosorbent test or other); previous pulmonary function tests; previous hospitalizations for asthma; probable cause of exacerbation; lowest arterial $\mathrm{pH}$ at hospital admission; $\mathrm{FEV}_{1} / \mathrm{PEF}$ ratio in the emergency room; admission to and length of stay in the ICU; overall length of hospital stay; cardiopulmonary arrest; intubation/mechanical ventilation during hospitalization; duration of intubation/mechanical ventilation; and in-hospital mortality. For the study of seasonal variations in the number of hospital admissions, the seasons were defined as follows: summer, July through September in the northern hemisphere and January through March in the southern hemisphere; fall, October through December in the northern hemisphere and April through June in the southern hemisphere; winter, January through March in the northern hemisphere and July through September in the southern hemisphere; and spring, April through June in the northern hemisphere and October through December in the southern hemisphere.

All data were analyzed using the program Statistical Package for the Social Sciences, version 12.0 for Windows (SPSS Inc., Chicago, IL, USA). For continuous variables, values were expressed as mean \pm standard deviation. Differences between groups were evaluated using one-way or two-way ANOVA. For categorical variables, the chi-square test with Yates' correction or Fisher's exact test was used. All statistical tests were two-tailed, and values of $p<0.05$ were considered significant. Standard formulas were used in order to calculate $95 \% \mathrm{Cls}$.

\section{Results}

A total of 3,038 asthma patients (37.5\% between 15 and 34 years of age; 32.5\% between 35 and 55 years of age; and 30.0\% between 
56 and 69 years of age) met the inclusion criteria and were evaluated (Table 1). Many of the patients presented severe, life-threatening exacerbations (PEF, 30-50\% of predicted in $49.2 \%$ of the sample).

In the analysis of data collected at hospital admission (stratified by year), we found that, over the years evaluated, there was a significant increase in age, in the proportion of female patients (72\% in 2004) and in asthma severity (Table 2). Most patients presented persistent asthma (moderate or severe). More than 50\% of the patients had previously been hospitalized due to asthma exacerbation. Although the overall use of inhaled corticosteroids and longacting $\beta_{2}$ agonists was low, it increased over the course of the ten-year study period, whereas the use of theophylline decreased over the same period. We found that the use of inhaled corticosteroids correlated significantly with asthma severity ( $p=0.001)$. Finally, there was a slight increase in the proportion of patients reporting being submitted to pulmonary function tests, and only a few patients reported having been submitted to allergy tests.

We found that the majority of hospitalizations occurred during the fall and winter seasons. Over the study period, there was a significant increase in the frequency of upper respiratory tract infections, together with a decrease in the number of cases in which the asthma attack had been triggered by aeroallergens. In addition, the proportion of patients with severe exacerbations increased significantly, although there was a decrease in the number of life-threatening attacks. Furthermore, the mean of the lowest arterial $\mathrm{pH}$ at admission increased significantly over the years evaluated. Moreover, we found that the proportion of cases in which
PEF was determined in the emergency room decreased significantly (from 33.3\% in 1994 to $26.1 \%$ in $2004, p=0.0001)$. However, there was also a significant decrease in the mean length of hospital stay (8.5 days in 1994, 7.4 days in 1999 and 7.1 days in 2004, $p=0.0001$ ). There were no significant changes in the frequency of ICU admission, cardiopulmonary arrest, intubation/mechanical ventilation or in-hospital death, although there was a trend toward lower in-hospital mortality.

The comparison between the hospitalizations occurring in Spain and those occurring in Latin America (stratified by year) showed that the patients hospitalized in Latin America were younger and more often had moderate or severe asthma. As can be seen in Table 3, the proportion of patients using inhaled corticosteroids was significantly lower among those hospitalized in Latin America than among those hospitalized in Spain $(26.3 \%$ vs. $56.4 \%$ in 2004 , $p=0.0001)$, as was the proportion of those using long-acting $\beta_{2}$ agonists (10.1\% vs. $43.3 \%$ in $2004, p=0.0001$ ). However, the proportion of patients using theophylline as a controller medication was significantly higher among those hospitalized in Latin America (17.4\% vs. $6.6 \%$ in $2004, p=0.0001)$. Upper respiratory tract infections were less often the cause of asthma exacerbation in patients hospitalized in Latin America than among those hospitalized in Spain, and the number of hospital admissions during the summer months was lower among the latter group. In addition, measurements of allergenicity were less frequently employed in Latin America. Furthermore, the patients hospitalized in Latin America presented higher rates of previous hospital admission and of intubation/mechanical ventilation. However,

Table 1 - Patients hospitalized with acute severe asthma in the nine countries evaluated, stratified by year.

\begin{tabular}{lcccc}
\hline \multicolumn{1}{c}{ Country } & 1994 & 1999 & 2004 & All years \\
\hline Argentina, $\mathrm{n}(\%)$ & $21(2.9)$ & $32(2.7)$ & $26(2.2)$ & $79(2.6)$ \\
Brazil, $\mathrm{n}(\%)$ & $44(6.1)$ & $40(3.4)$ & $39(3.4)$ & $123(4.0)$ \\
Chile, $\mathrm{n}(\%)$ & 0 & $91(7.8)$ & $81(7.0)$ & $172(4.0)$ \\
Colombia, $\mathrm{n}(\%)$ & $3(0.4)$ & $54(4.6)$ & $128(11.1)$ & $185(6.1)$ \\
Mexico, $\mathrm{n}(\%)$ & $157(21.9)$ & $207(17.8)$ & $120(10.4)$ & $484(15.9)$ \\
Peru, $\mathrm{n}(\%)$ & $15(2.1)$ & $18(1.5)$ & $26(2.3)$ & $59(1.9)$ \\
Spain, $\mathrm{n}(\%)$ & $393(54.7)$ & $647(55.5)$ & $673(58.3)$ & $1713(56.4)$ \\
Uruguay, $\mathrm{n}(\%)$ & $53(7.4)$ & $44(3.8)$ & $39(3.4)$ & $136(4.5)$ \\
Venezuela, $\mathrm{n}(\%)$ & $32(4.5)$ & $33(2.8)$ & $22(1.9)$ & $87(2.9)$ \\
All, $\mathrm{n}(\%)$ & $718(23.6)$ & $1,166(38.4)$ & $1,154(38.0)$ & $3,038(100.0)$ \\
\hline
\end{tabular}


Table 2 - Characteristics of all patients hospitalized with acute severe asthma, stratified by year.

\begin{tabular}{|c|c|c|c|c|c|}
\hline \multirow{2}{*}{$\begin{array}{l}\text { Pre-admission variables and variables } \\
\text { related to the admissions evaluated }\end{array}$} & 1994 & 1999 & 2004 & \multirow[t]{2}{*}{$\mathrm{p}$} & All years \\
\hline & $(n=718)$ & $(n=1,166)$ & $(\mathrm{n}=, 1154)$ & & $(n=3,038)$ \\
\hline \multicolumn{6}{|l|}{ Pre-admission } \\
\hline Age in years, mean $\pm S D$ & $38.0 \pm 19.5$ & $42.2 \pm 20.0$ & $45.1 \pm 17.7$ & 0.0001 & $42.3 \pm 19.2$ \\
\hline Gender (M/F), \% & $33.6 / 66.4$ & $31.8 / 68.2$ & 28.0/72.0 & 0.02 & $30.7 / 69.3$ \\
\hline Asthma severity, $\%$ & & & & 0.0001 & \\
\hline Intermittent & 15.7 & 18.9 & 20.5 & & 18.7 \\
\hline Mild & 23.3 & 16.9 & 16.9 & & 18.3 \\
\hline Moderate & 40.8 & 34.0 & 31.9 & & 34.9 \\
\hline Severe & 20.2 & 30.2 & 30.7 & & 28.1 \\
\hline Hospitalizations, \% & 58.2 & 58.6 & 59.7 & 0.7 & 58.9 \\
\hline Use of inhaled corticosteroids, $\%$ & 23.8 & 27.0 & 43.5 & 0.0001 & 32.6 \\
\hline ICS dose $(\mu \mathrm{g})$, mean \pm SD & $847 \pm 506$ & $833 \pm 450$ & $966 \pm 421$ & 0.0001 & $897 \pm 452$ \\
\hline Use of LABAs, $\%$ & 0.6 & 8.9 & 29.1 & 0.0001 & 14.5 \\
\hline Use of theophylline, \% & 29.1 & 16.7 & 11.2 & 0.0001 & 17.3 \\
\hline Allergy tests, \% & 33.5 & 38.5 & 41.5 & 0.02 & 38.2 \\
\hline Pulmonary function tests, \% & 37.6 & 50.6 & 44.9 & 0.0001 & 45.4 \\
\hline \multicolumn{6}{|l|}{ At admission or during hospitalization } \\
\hline \multicolumn{6}{|l|}{ Season of admission, $\%$} \\
\hline Summer & 21.6 & 19.8 & 21.4 & 0.0001 & 20.8 \\
\hline Fall & 28.1 & 32.7 & 26.5 & & 29.3 \\
\hline Winter & 27.7 & 31.1 & 28.6 & & 29.4 \\
\hline Spring & 22.6 & 16.4 & 23.5 & & 20.5 \\
\hline Exacerbation cause, $\%$ & & & & 0.0001 & \\
\hline URTI & 50.1 & 61.9 & 28.8 & & 57.8 \\
\hline Pneumonia & 4.8 & 6.1 & 6.2 & & 5.8 \\
\hline Aeroallergens & 8.6 & 4.0 & 2.6 & & 4.6 \\
\hline Other & 7.9 & 5.5 & 5.7 & & 6.3 \\
\hline Unknown & 28.6 & 22.5 & 26.7 & & 25.5 \\
\hline PEF determined in the ER, \% & 33.3 & 22.9 & 26.1 & 0.0001 & 26.6 \\
\hline$\%$ predicted PEF in the ER, mean \pm SD & $41.5 \pm 17.5$ & $40.4 \pm 14.3$ & $43.7 \pm 16.3$ & 0.04 & $42.6 \pm 16.3$ \\
\hline \multicolumn{6}{|l|}{ Exacerbation severity, $\%$} \\
\hline Mild-moderate & 24.7 & 19.9 & 26.0 & 0.01 & 23.6 \\
\hline Severe & 41.4 & 53.9 & 51.3 & & 49.2 \\
\hline Life-threatening & 33.9 & 26.2 & 22.7 & & 27.2 \\
\hline length of hospitalization (days), mean \pm SD & $8.5 \pm 7.2$ & $7.4 \pm 4.7$ & $7.1 \pm 5.6$ & 0.0001 & $7.5 \pm 5.7$ \\
\hline Lowest arterial $\mathrm{pH}$, mean $\pm \mathrm{SD}$ & $7.38 \pm 0.09$ & $7.40 \pm 0.08$ & $7.40 \pm 0.08$ & 0.0001 & $7.39 \pm 0.08$ \\
\hline ICU admission, \% & 7.8 & 6.1 & 6.8 & 0.3 & 6.3 \\
\hline Length of ICU stay (h), mean \pm SD & $71.2 \pm 136.6$ & $56.4 \pm 112.6$ & $65.9 \pm 71.3$ & 0.7 & $67.7 \pm 106.3$ \\
\hline Intubation/MV, \% & 5.0 & 5.6 & 6.6 & 0.3 & 5.3 \\
\hline Cardiopulmonary arrest, \% & 2.9 & 2.7 & 1.8 & 0.2 & 2.4 \\
\hline Death, \% & 1.0 & 0.9 & 0.7 & 0.7 & 0.8 \\
\hline
\end{tabular}

ER; emergency room; ICU; intensive care unit; LABAs; long-acting $\beta_{2}$ agonists; MV; mechanical ventilation; and URTI; upper respiratory tract infection.

PEF determination in the emergency room was more often employed at the hospitals in Latin America, although there were no differences in the percentage of predicted PEF.

Patients hospitalized in Spain were more often submitted to pulmonary function tests and allergy tests than were those hospitalized in Latin America. Over the course of the study period, the patients hospitalized in Spain also presented an increase in the mean of the lowest arterial $\mathrm{pH}$ at admission, a significant reduction in the length of the hospital stay and a significant decrease 
Table 3 - Differences between asthma patients hospitalized in Spain and those hospitalized in Latin America, stratified by year.

\begin{tabular}{|c|c|c|c|c|c|c|c|}
\hline \multirow{3}{*}{$\begin{array}{l}\text { Pre-admission variables } \\
\text { and variables related to the } \\
\text { admissions evaluated }\end{array}$} & \multicolumn{3}{|c|}{ Spain } & \multicolumn{3}{|c|}{ Latin America } & \multirow[t]{3}{*}{$p$} \\
\hline & 1994 & 1998 & 2004 & 1994 & 1998 & 2004 & \\
\hline & $(n=393)$ & $(n=647)$ & $(n=673)$ & $(n=321)$ & $(n=511)$ & $(n=493)$ & \\
\hline \multicolumn{8}{|l|}{ At admission } \\
\hline Age in years, mean $\pm S D$ & $\begin{array}{c}43.2 \pm \\
17.1\end{array}$ & $\begin{array}{c}45.0 \pm \\
18.0\end{array}$ & $\begin{array}{c}47.7 \pm \\
17.4\end{array}$ & $\begin{array}{l}31.7 \pm \\
20.3\end{array}$ & $\begin{array}{c}38.7 \pm \\
21.7\end{array}$ & $\begin{array}{c}41.5 \pm \\
17.4\end{array}$ & 0.0001 \\
\hline Gender (M/F), \% & 30.5 & 31.5 & 27.7 & 37.2 & 32.2 & 28.2 & 0.2 \\
\hline Asthma severity, \% & & & & & & & 0.0001 \\
\hline Intermittent & 20.6 & 23.4 & 22.5 & 10.3 & 14.4 & 18.2 & \\
\hline Mild & 23.1 & 18.4 & 18.7 & 23.6 & 15.4 & 14.8 & \\
\hline Moderate & 33.0 & 32.4 & 34.3 & 49.3 & 35.6 & 29.3 & \\
\hline Severe & 23.4 & 25.8 & 37.7 & 16.8 & 34.6 & 37.7 & \\
\hline Hospitalizations, $\%$ & 58.6 & 54.5 & 57.1 & 57.8 & 63.8 & 65.5 & 0.002 \\
\hline Use of inhaled corticosteroids, $\%$ & 38.4 & 41.7 & 56.4 & 7.9 & 9.4 & 26.3 & 0.0001 \\
\hline Use of LABAs, \% & 1.2 & 13.5 & 43.3 & 0 & 3.5 & 10.1 & 0.0001 \\
\hline Use of theophylline, \% & 23.2 & 12.0 & 6.6 & 35.8 & 22.7 & 17.4 & 0.0001 \\
\hline Allergy tests, \% & 56.3 & 54.5 & 54.0 & 4.7 & 22.2 & 20.8 & 0.0001 \\
\hline Pulmonary function tests, $\%$ & 45.2 & 55.0 & 51.8 & 28.3 & 44.8 & 35.3 & 0.0001 \\
\hline \multicolumn{8}{|l|}{ At admission or during hospitalization } \\
\hline Season of admission, $\%$ & & & & & & & 0.0001 \\
\hline Summer & 16.8 & 17.3 & 18.4 & 27.4 & 22.9 & 25.6 & \\
\hline Fall & 26.5 & 32.9 & 27.8 & 30.2 & 32.4 & 24.7 & \\
\hline Winter & 31.0 & 33.2 & 27.8 & 23.7 & 28.5 & 29.7 & \\
\hline Spring & 25.7 & 16.5 & 26.0 & 18.8 & 16.2 & 20.0 & \\
\hline Exacerbation cause, $\%$ & & & & & & & 0.0001 \\
\hline URTl & 58.6 & 66.9 & 66.4 & 39.7 & 55.6 & 47.9 & \\
\hline Pneumonia & 3.3 & 3.3 & 3.8 & 6.6 & 9.5 & 9.6 & \\
\hline Aeroallergens & 5.1 & 4.1 & 2.3 & 12.8 & 4.1 & 3.3 & \\
\hline Other & 4.9 & 2.7 & 3.9 & 11.8 & 9.1 & 8.1 & \\
\hline Unknown & 28.1 & 23.0 & 23.6 & 29.1 & 21.7 & 31.1 & \\
\hline PEF determined in the ER, \% & 20.6 & 18.0 & 13.7 & 48.6 & 29.1 & 43.5 & 0.0001 \\
\hline $\begin{array}{l}\% \text { predicted PEF in the ER, } \\
\text { mean } \pm S D\end{array}$ & $\begin{array}{c}42.6 \pm \\
18.0\end{array}$ & $\begin{array}{c}39.9 \pm \\
13.6\end{array}$ & $\begin{array}{c}40.5 \pm \\
14.3\end{array}$ & $\begin{array}{c}40.0 \pm \\
17.1\end{array}$ & $\begin{array}{c}40.8 \pm \\
14.8\end{array}$ & $\begin{array}{c}43.5 \pm \\
16.9\end{array}$ & 0.2 \\
\hline Exacerbation severity, \% & & & & & & & 0.3 \\
\hline Mild-moderate & 30.9 & 18.1 & 20.6 & 21.5 & 21.2 & 30.6 & \\
\hline Severe & 43.2 & 56.9 & 51.4 & 40.5 & 51.7 & 51.2 & \\
\hline Life-threatening & 25.9 & 25.0 & 33.0 & 38.0 & 27.1 & 18.2 & \\
\hline $\begin{array}{l}\text { Length of hospitalization (days), } \\
\text { mean } \pm \text { SD }\end{array}$ & $\begin{array}{c}8.7 \pm \\
6.7\end{array}$ & $\begin{array}{c}7.4 \pm \\
4.3\end{array}$ & $\begin{array}{c}6.9 \pm \\
5.0\end{array}$ & $\begin{array}{c}8.2 \pm \\
7.6\end{array}$ & $\begin{array}{c}7.5 \pm \\
5.1\end{array}$ & $\begin{array}{c}7.3 \pm \\
6.5\end{array}$ & 0.8 \\
\hline $\begin{array}{l}\text { Lowest arterial pH, } \\
\text { mean } \pm \mathrm{SD}\end{array}$ & $\begin{array}{c}7.38 \pm \\
0.09\end{array}$ & $\begin{array}{c}7.40 \pm \\
0.07\end{array}$ & $\begin{array}{c}7.40 \pm \\
0.07\end{array}$ & $\begin{array}{l}7.38 \pm \\
0.09\end{array}$ & $\begin{array}{c}7.39 \pm \\
0.08\end{array}$ & $\begin{array}{l}7.40 \pm \\
0.09\end{array}$ & 0.2 \\
\hline ICU admission, \% & 7.4 & 4.5 & 3.7 & 8.3 & 8.1 & 11.2 & 0.0001 \\
\hline $\begin{array}{l}\text { Length of ICU stay (h), } \\
\text { mean } \pm \text { SD }\end{array}$ & $\begin{array}{r}92.7 \pm \\
185.6\end{array}$ & $\begin{array}{c}73.6 \pm \\
167.7\end{array}$ & $\begin{array}{c}37.4 \pm \\
40.2\end{array}$ & $\begin{array}{c}48.1 \pm \\
36.2\end{array}$ & $\begin{array}{c}44.5 \pm \\
45.6\end{array}$ & $\begin{array}{c}78.7 \pm \\
79.2\end{array}$ & 0.5 \\
\hline Intubation/MV, \% & 3.3 & 4.9 & 4.6 & 5.5 & 5.8 & 8.1 & 0.01 \\
\hline Cardiopulmonary arrest, $\%$ & 3.6 & 2.3 & 2.1 & 2.2 & 3.1 & 2.1 & 0.8 \\
\hline Death, $\%$ & 1.0 & 0.6 & 1.0 & 0.9 & 1.2 & 0.8 & 0.8 \\
\hline
\end{tabular}

ER; emergency room; ICU; intensive care unit; LABAs; long-acting $\beta_{2}$ agonists; MV; mechanical ventilation; and URTI; upper respiratory tract infection. 
Table 4 - Characteristics of all hospitalized patients stratified by intensive care unit admission and in-hospital death.

\begin{tabular}{|c|c|c|c|c|c|c|}
\hline \multirow{3}{*}{$\begin{array}{c}\text { Pre-admission variables and } \\
\text { variables related to the admissions } \\
\text { evaluated }\end{array}$} & \multicolumn{2}{|c|}{ ICU Admission } & \multirow[t]{3}{*}{$p$} & \multicolumn{2}{|c|}{ Death } & \multirow[t]{3}{*}{$p$} \\
\hline & Yes & No & & Yes & No & \\
\hline & $(n=206)$ & $(n=2831)$ & & $(n=23)$ & $(n=3015)$ & \\
\hline \multicolumn{7}{|l|}{ At admission } \\
\hline Age in years, mean \pm SD & $43.5 \pm 19.6$ & $42.2 \pm 19.3$ & 0.3 & $58.6 \pm 18.8$ & $42.2 \pm 19.1$ & 0.0001 \\
\hline Gender (M/F), \% & $32.0 / 68.0$ & $30.7 / 69.3$ & 0.7 & $8.0 / 92.0$ & $31.0 / 69.0$ & 0.02 \\
\hline Asthma severity, $\%$ & & & 0.0001 & & & 0.001 \\
\hline Intermittent & 10.3 & 19.4 & & 0 & 18.9 & \\
\hline Mild & 9.2 & 19.1 & & 8.7 & 18.5 & \\
\hline Moderate & 33.3 & 34.9 & & 26.1 & 34.9 & \\
\hline Severe & 42.1 & 26.7 & & 65.2 & 27.7 & \\
\hline Hospitalizations, \% & 72.7 & 57.9 & 0.0001 & 70.8 & 58.8 & 0.3 \\
\hline Use of inhaled corticosteroids, $\%$ & 29.6 & 32.9 & 0.3 & 41.7 & 32.6 & 0.3 \\
\hline Use of LABAs, $\%$ & 11.1 & 15.3 & 0.1 & 18.2 & 15.0 & 0.9 \\
\hline Use of theophylline, $\%$ & 32.1 & 16.3 & 0.0001 & 41.7 & 17.2 & 0.004 \\
\hline Allergy tests, $\%$ & 45.6 & 42.2 & 0.3 & 54.7 & 48.0 & 0.6 \\
\hline \multicolumn{7}{|l|}{ At admission or during hospitalization } \\
\hline Season of admission, $\%$ & & & 0.9 & & & 0.03 \\
\hline Summer & 19.9 & 20.9 & & 8.0 & 20.9 & \\
\hline Fall & 30.1 & 29.2 & & 32.0 & 29.2 & \\
\hline Winter & 29.1 & 29.4 & & 52.0 & 29.2 & \\
\hline Spring & 20.9 & 20.5 & & 8.0 & 20.6 & \\
\hline Exacerbation cause, $\%$ & & & 0.0001 & & & 0.3 \\
\hline URTI & 31.7 & 59.6 & & 40.0 & 58.0 & \\
\hline Pneumonia & 12.1 & 5.3 & & 16.0 & 5.7 & \\
\hline Aeroallergens & 7.5 & 4.4 & & 0 & 4.6 & \\
\hline Other & 17.0 & 5.6 & & 12.0 & 6.3 & \\
\hline Unknown & 31.7 & 25.1 & & 32.0 & 25.4 & \\
\hline PEF determined in the ER, $\%$ & 34.0 & 26.0 & 0.01 & 24.0 & 26.6 & 0.9 \\
\hline $\begin{array}{l}\% \text { predicted } \mathrm{PEF} \text { in the } \mathrm{ER}, \\
\text { mean } \pm \mathrm{SD}\end{array}$ & $34.1 \pm 12.7$ & $42.7 \pm 16.2$ & 0.0001 & $27.0 \pm 9.1$ & $42.1 \pm 16.1$ & 0.002 \\
\hline $\begin{array}{l}\text { Length of hospitalization (days), } \\
\text { mean } \pm \text { SD }\end{array}$ & $11.0 \pm 8.3$ & $7.3 \pm 5.4$ & 0.0001 & $11.9 \pm 12.2$ & $7.5 \pm 5.6$ & 0.0001 \\
\hline Lowest arterial $\mathrm{pH}$, mean $\pm \mathrm{SD}$ & $7.25 \pm 0.15$ & $7.41 \pm 0.06$ & 0.0001 & $7.20 \pm 0.1$ & $7.40 \pm 0.08$ & 0.0001 \\
\hline ICU admissions, \% & & & & 68.0 & 6.3 & 0.0001 \\
\hline Intubation/MV, \% & 20.9 & 4.2 & 0.0001 & 16.0 & 5.3 & 0.05 \\
\hline Cardiopulmonary arrest,\% $\%$ & 33.0 & 0.2 & 0.0001 & 72.0 & 1.8 & 0.0001 \\
\hline Deaths, $\%$ & 8.3 & 0.3 & 0.0001 & & & \\
\hline
\end{tabular}

ER; emergency room; ICU; intensive care unit; LABAs; long-acting $\beta_{2}$ agonists; MV; mechanical ventilation; and URTI; upper respiratory tract infection.

in the frequency of ICU admission. Regardless of the degree of asthma severity, the proportion of patients receiving inhaled corticosteroids was higher among those hospitalized in Spain than among those hospitalized in Latin America. However, there were no differences between the two groups in terms of the frequency of cardiopulmonary arrest or the mortality rate.
Of the 3,038 patients who were hospitalized during the years evaluated, 206 (6.8\%) were admitted to ICU (Table 4). These patients, compared with those who were not admitted to the $1 \mathrm{CU}$, presented greater asthma severity. In addition, the proportion of patients who had previously been hospitalized was higher among those admitted to the $\mathrm{ICU}$, as was the propor- 
tion of those who used theophylline, those with a history of pneumonia and those in whom the asthma attack had been triggered by aeroallergens. Furthermore, upper respiratory tract infections were less common among patients admitted to the ICU. Although the majority of ICU admissions occurred during the fall and winter seasons, there was no difference between patients admitted and not admitted to the $1 \mathrm{CU}$ in terms of the season of admission. The patients admitted to the ICU presented greater exacerbation severity (lower mean arterial $\mathrm{pH}$, lower mean PEF and longer length of hospital stay), as well as higher rates of intubation/mechanical ventilation, cardiopulmonary arrest and in-hospital death.

There were 23 in-hospital deaths $(0.8 \%$ of all hospitalized patients) during the three years studied. As would be expected, the rates of cardiopulmonary arrest, intubation/mechanical ventilation and ICU admission were higher among the asthma patients who died during hospitalization. Among the patients admitted to the $1 \mathrm{CU}$, the overall mortality rate was $8.3 \%$ and the mortality rate for those who suffered cardiopulmonary arrest was $24.7 \%$. The mortality rate among hospitalized patients who were submitted to intubation/mechanical ventilation was $2.5 \%$ (Figure 1). Asthma severity and the frequency of previous exacerbations were greater among the

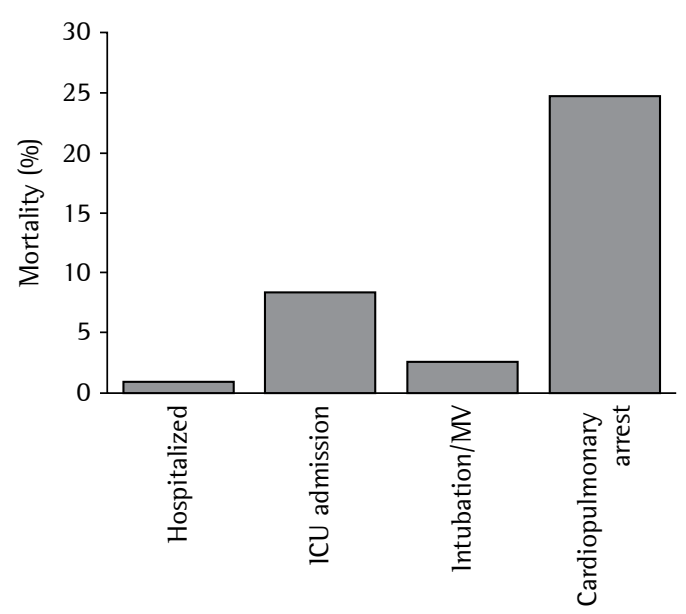

Figure 1 - Mortality rates (1994, 1998 and 2004 combined) among patients hospitalized with acute severe asthma and, within that population, among those admitted to the intensive care unit (ICU), those submitted to intubation/mechanical ventilation (MV) and those suffering cardiopulmonary arrest. nonsurviving patients. Nearly all (95\%) of the deaths occurred in female patients. There was a relationship between death and patient age, most of the asthma-related deaths occurring in patients > 50 years of age $(<35$ years, 12\%; $35-50$ years, $20 \%$; and $>50$ years, $68 \%$ ). Among the nonsurviving patients, hospital stays were longer, and the proportion of patients using theophylline was higher. Unlike ICU admissions, in-hospital death from asthma presented a seasonal variation, peaking during the winter months.

\section{Discussion}

The objective of this retrospective, international, multicenter study was to evaluate changes in the characteristics of patients hospitalized for acute severe asthma during a ten-year period in Spain and in eight Latin-American countries. To that end, we reviewed all hospital records for patients admitted at nineteen tertiary-care hospitals in 1994, 1999 and 2004. The data obtained indicate a significant overall improvement in the management of asthma patients between severe attacks and during hospitalizations (in terms of controller medication use and length of hospital stay).

The severe asthma patients hospitalized later in the study period presented less physiological severity, as evidenced by higher arterial $\mathrm{pH}$ at admission and higher percentage of predicted PEF in the emergency room. These trends have been reported previously. ${ }^{(5,9)}$ In addition, we observed a trend toward a reduction of in-hospital mortality. The in-hospital mortality rate for all patients hospitalized during the three years studied was 0.8\% (95\% Cl: 0.6-1.2), which is in accordance with previous estimates of in-hospital mortality at individual hospitals and in ICU units, as well as with nationally representative data. ${ }^{(9,10)}$ Furthermore, there was a reduction in the frequency of cardiopulmonary arrest (2.9\% in $1994,2.7 \%$ in 1999 and $1.8 \%$ in 2004) although the difference was not statistically significant $(p=0.2)$.

Any optimism generated by the apparent improvements in certain aspects of asthma care over the course of the period studied is tempered by the lack of such improvements, or even a decline in the standard of care, in other aspects. One such aspect is the use of PEF measurement in the emergency room, which decreased 
significantly. A recent prospective study on the management of patients hospitalized with acute asthma in Spain reported that PEF had been determined in only 30\% of the patients. ${ }^{(11)}$ It is well established that measurements of lung function, such as $\mathrm{FEV}_{1} / \mathrm{PEF}$, provide an objective evaluation of airway obstruction and constitute an integral part of the assessment of disease severity (static assessment) and of the response to therapy (dynamic assessment) in any patient over 5 years of age. ${ }^{(1,3,12)}$ This suggests that acute asthma patients are being admitted, treated and discharged inappropriately. The reasons for the lack of more intensive use of PEF determination in emergency rooms are not clear, although influencing factors include emergency room congestion and physician time fragmentation, both of which are inherent to the day-to-day practice of emergency medicine. ${ }^{(13,14)}$ In the present study, other important variables, such as ICU admission (in 6.5\%), history of previous admissions (in 58.9\%) and intubation/mechanical ventilation (in 5.3\%), remained unchanged or trended lower over the ten-year study period.

We found that mean patient age and the proportion of female patients increased over the course of the study period, This is in agreement with previous findings, ${ }^{(15,16)}$ and it has been suggested that gender-related differences are attributable to hormonal influences, although no specific mechanism has been postulated. ${ }^{(17)}$ There was a seasonal distribution of asthmarelated hospitalizations, admissions peaking during the fall and winter seasons. This seasonal peak occurred in months without peak pollen counts and tended to be more closely correlated with the viral respiratory season. ${ }^{(9,18)}$ Viral respiratory tract infections have been associated with asthma exacerbations in children and adults. ${ }^{(19,20)}$ In fact, the seasonal peak observed in the present study was related to an increase in the frequency of upper respiratory tract infections and of pneumonia, as well as with a decrease in the proportion of cases in which the asthma attack was triggered by aeroallergens.

When the patient sample was stratified by hemisphere (Spain vs. Latin America), certain differences became evident. The standards of asthma management between exacerbations (assessing allergenicity and performing pulmonary function tests) were found to be higher in Spain, where the number of previous hospitaliza- tions was also lower. The proportion of patients receiving inhaled corticosteroids and longacting $\beta_{2}$ agonists was higher in Spain, whereas that of those using theophylline as a controller medication was lower. Accordingly, the degree of asthma severity was lower among the patients hospitalized in Spain, and those patients apparently received better in-hospital care (rates of ICU admission and intubation/mechanical ventilation were lower). Regardless of geographic location, there was a direct correlation between the use of inhaled corticosteroids and asthma severity. However, one disturbing finding was that the use of anti-inflammatory drugs among patients with moderate-to-severe persistent asthma was low $(\approx 20 \%)$ in Latin America, suggesting that a considerable number of these patients received suboptimal treatment.

We found that, in Spain and in Latin America, there was insufficient objective monitoring of asthma between exacerbations. Despite the fact that one of the goals of the Global Initiative for Asthma is to achieve normal or near normal lung function, ${ }^{(1)}$ pulmonary function tests had previously been performed in only $51.8 \%$ of the patients hospitalized in Spain and in only 35.5\% of the patients hospitalized in Latin America. These data are in agreement with those obtained in previous studies conducted in Europe and Latin America. ${ }^{(21,22)}$

Our data regarding $\mathrm{ICU}$ admissions and in-hospital deaths are consistent with previous findings. ${ }^{(7)}$ In the present study, $6.7 \%$ of all hospitalized asthma patients required ICU admission, and the mortality rate among patients admitted to the ICU was 8.3\%. Few patients were submitted to intubation/mechanical ventilation, and the mortality rate among such patients was low (2.5\%). Similarly, several studies conducted during the last two decades have reported mortality rates ranging from $0 \%$ to $6 \% .{ }^{(23-25)}$ In contrast, mortality was significantly higher among patients suffering cardiopulmonary arrest $(24.7 \%)$. Deaths occurred almost exclusively in female asthma patients and in patients > 55 years of age. Factors associated with mortality were analyzed in a separate publication based on the EAGLE data. ${ }^{(26)}$

This study has a number of limitations. Despite its international and multicenter character, it was performed retrospectively, and the analysis was restricted to three discrete 
time periods. Therefore, it is possible that not all patient charts were located in the studied years, and that continuous data do not present the same trends in patients hospitalized with acute severe asthma. In addition, there were no standardized admission criteria, and some patients, especially those over 50 years of age (typical of patients with COPD), might therefore have been misdiagnosed. The study was designed to permit temporal changes to be observed and not to explain the reasons for such changes. Furthermore, although we selected a large sample of hospitalized asthma patients from nineteen hospitals in Spain and Latin America, the results are not necessarily representative of all patients hospitalized with acute severe asthma. In fact, due to the sample characteristics, patients hospitalized in Spain were probably much better represented than were their counterparts in Latin America. Moreover, it is likely that there are significant differences between Spain and Latin America, as well as among Latin-American countries, in terms of the characteristics of their health care systems. The potential impact of these differences should be considered in the evaluation of the characteristics of hospitalized asthma patients.

In conclusion, our findings suggest that there have been some improvements in the management of asthma between severe exacerbations and during hospitalizations. However, over the ten-year study period, the standard of care apparently decreased in certain aspects (e.g., PEF determination in the emergency room), and some indicators (rates of mortality, intubation/mechanical ventilation and ICU admission) remained unchanged. In general, asthma patients hospitalized in Spain had access to a better standard of management and care than did those hospitalized in Latin America.

\section{Acknowledgments}

EAGLE Investigators: Argentina: $\mathrm{R}$ Gené (Hospital de Clínicas, Buenos Aires) and LJ Nannini (Hospital General Baigorria, Rosario); Brazil: R Stirbulov (Santa Casa de São Paulo, São Paulo); Chile: R Sepúlveda (Thoracic Institute, Santiago); Colombia: 1 Solarte (Columbian Pulmonology Foundation, Bogotá); Mexico: J Salas (National Respiratory Diseases Institute, Mexico City); Peru: M Tsukayama (Ricardo Palma Clinic, Lima); Spain: J Armengol (Hospital de
Terrassa, Terassa), S Bardagi (Hospital de Mataró, Mataró), MT Bazús (National Silicosis Institute, Oviedo), J Bellido (Hospital de la Santa Creu $i$ Sant Pau, Barcelona), AJ Cosano (Hospital Rein Sofi, Córdoba), A Lopez-Viña (Hospital Puerta de Hierro, Madrid), E Martinez Moragón (Hospital de Sagunto, Sagunto), M Perpiñá (Hospital La Fe, Valencia), V Plaza (Hospital de la Santa Creu i Sant Pau, Barcelona), G Rodriguez-Trigo (Hospital Juan Canalejo, La Coruña) and J Sanchis (Hospital de la Santa Creu i Sant Pau, Barcelona), Uruguay: L Piñeyro (Hospital Maciel, Montevideo) and GJ Rodrigo (Hospital Central de las Fuerzas Armadas, Montevideo); Venezuela: G Levy (Hospital Universitario, Caracas).

\section{References}

1. Global Initiative for Asthma - GINA [homepage on the Internet]. Bethesda: National Heart, Lung and Blood Institute. National Institutes of Health, US Department of Health and Human Services; c2000 [cited 2008 Nov 15]. Available from: http://www.ginasthma.org

2. Centers for Disease Control and Prevention [homepage on the Internet]. Atlanta: Centers for Disease Control and Prevention. [cited 2008 Sep 10]. Asthma. Available from: www.cdc.gov/asthma/asthmadata.htm.

3. Rodrigo GJ, Rodrigo C, Hall JB. Acute asthma in adults: a review. Chest. 2004;125(3):1081-102.

4. Salmeron S, Liard R, Elkharrat D, Muir J, Neukirch F, Ellrodt A. Asthma severity and adequacy of management in accident and emergency departments in France: a prospective study. Lancet. 2001;358(9282):629-35.

5. Han P, Cole RP. Evolving differences in the presentation of severe asthma requiring intensive care unit admission. Respiration. 2004;71(5):458-62.

6. Kuo E, Kesten S. A retrospective comparative study of in-hospital management of acute severe asthma: 1984 vs 1989. Chest. 1993;103(6):1655-61.

7. Afessa B, Morales 1, Cury JD. Clinical course and outcome of patients admitted to an ICU for status asthmaticus. Chest. 2001;120(5):1616-21.

8. Vargas MH, Díaz-Mejía GS, Furuya ME, Salas J, Lugo A. Trends of asthma in Mexico: an 11-year analysis in a nationwide institution. Chest. 2004;125(6):1993-7.

9. Krishnan V, Diette GB, Rand CS, Bilderback AL, Merriman B, Hansel NN, et al. Mortality in patients hospitalized for asthma exacerbations in the United States. Am J Respir Crit Care Med. 2006;174(6):633-8.

10. Pendergraft TB, Stanford RH, Beasley R, Stempel DA, Roberts C, McLaughlin T. Rates and characteristics of intensive care unit admissions and intubations among asthma-related hospitalizations. Ann Allergy Asthma Immunol. 2004;93(1):29-35.

11. Borderías Clau L, Zabaleta Murgionda M, Riesco Miranda JA, Pellicer Ciscar C, Hernández Hernández JR, Carrillo Díaz T, et al. Coste y manejo de una crisis asmática en el ámbito hospitalario de nuestro medio (estudio COAX en servicios hospitalarios). Arch Bronconeumol. 2005;41(6):313-321. 
12. Rodrigo G, Rodrigo C. Early prediction of poor response in acute asthma patients in the emergency department. Chest. 1998;114(4):1016-21.

13. Kellermann AL. Crisis in the emergency department. $\mathrm{N}$ Engl J Med. 2006;355(13):1300-3.

14. Derlet RW. Overcrowding in emergency departments: increased demand and decreased capacity. Ann Emerg Med. 2002;39(4):430-2.

15. Johnston NW, Sears MR. Asthma exacerbations . 1: epidemiology. Thorax. 2006;61(8):722-8.

16. Otero González 1, Blanco Aparicio M, Montero Martínez C, Valiño López P. Verea Hernando H. Características epidemiológicas de las exacerbaciones por EPOC y asma en un hospital general. Arch Bronconeumol. 2002;38(6):256-62.

17. Brenner BE, Holmes TM, Mazal B, Camargo CA Jr. Relation between phase of the menstrual cycle and asthma presentations in the emergency department. Thorax. 2005;60(10):806-9.

18. Johnston SL, Pattemore PK, Sanderson G, Smith S, Campbell MJ, Josephs LK, et al. The relationship between upper respiratory infections and hospital admissions for asthma: a time-trend analysis. Am J Respir Crit Care Med. 1996;154(3 Pt 1):654-60.

19. Johnston NW, Johnston SL, Duncan JM, Greene JM, Kebadze T, Keith PK, et al. The September epidemic of asthma exacerbations in children: a search for etiology. J Allergy Clin Immunol. 2005;115(1):132-8.

20. Sykes A, Johnston SL. Etiology of asthma exacerbations. J Allergy Clin Immunol. 2008;122(4):685-8.

21. Rabe KF, Vermeire PA, Soriano JB, Maier WC. Clinical management of asthma in 1999: the Asthma lnsights and Reality in Europe (AIRE) study. Eur Respir J. 2000;16(5):802-7.

22. Neffen H, Fritscher C, Schacht FC, Levy G, Chiarella P, Soriano JB, et al. Asthma control in Latin America: the Asthma Insights and Reality in Latin America (AIRLA) survey. Rev Panam Salud Publica. 2005;17(3):191-7.

23. Zimmerman JL, Dellinger RP, Shah AN, Taylor RW. Endotracheal intubation and mechanical ventilation in severe asthma. Crit Care Med. 1993;21(11):1727-30.

24. Shapiro JM. Intensive care management of status asthmaticus. Chest. 2001;120(5):1439-41.

25. Stow PJ, Pilcher D, Wilson J, George C, Bailey M, Higlett $\mathrm{T}$, et al. Improved outcomes from acute severe asthma in Australian intensive care units (1996 2003). Thorax. 2007;62(10):842-7.

26. Rodrigo GJ, Plaza V, Forns BS, Tordera MP, Salas J. Factors associated with mortality in patients hospitalized in Spain and Latin America for acute severe asthma in 1994, 1999, and 2004. J Bras Pneumol. 2008;34(8):546-51.

\section{About the authors}

\section{Gustavo Javier Rodrigo}

Physician. Department of Emergency Services, Hospital Central de las Fuerzas Armadas, Montevideo, Uruguay.

\section{Vicente Plaza}

Physician. Department of Pulmonology, Hospital de la Santa Creu i Sant Pau, Barcelona, Spain.

\section{Jesús Bellido-Casado}

Physician. Department of Pulmonology, Hospital de la Santa Creu i Sant Pau, Barcelona, Spain.

\section{Hugo Neffen}

Physician. Department of Respiratory Medicine, Hospital de Niños “O. Allassia”, Santa Fe, Argentina.

\section{María Teresa Bazús}

Physician. Department of Pulmonology, National Silicosis Institute, Oviedo, Spain.

\section{Gur Levy}

Physician. Department of Pulmonology, Hospital Universitario de Caracas, Central University of Venezuela, Caracas, Venezuela.

\section{Joseph Armengol}

Physician. Department of Pulmonology, Hospital de Terrassa, Terrassa, Spain. 